\title{
Using Multiple-Point Geostatistics for Tracer Test Modeling in a Clay-Drape Environment with Spatially Variable Conductivity and Sorption Coefficient
}

\author{
Marijke Huysmans • Philippe Orban • Elke Cochet • Mathias Possemiers • \\ Benedicta Ronchi · Katherine Lauriks • Okke Batelaan • Alain Dassargues
}

Received: 14 January 2013 / Accepted: 30 October 2013

(C) International Association for Mathematical Geosciences 2013

\begin{abstract}
This study investigates the effect of fine-scale clay drapes on tracer transport. A tracer test was performed in a sandbar deposit consisting of cross-bedded sandy units intercalated with many fine-scale clay drapes. The heterogeneous spatial distribution of the clay drapes causes a spatially variable hydraulic conductivity and sorption coefficient. A fluorescent tracer (sodium naphthionate) was injected in two injection wells and ground water was sampled and analyzed from five pumping wells. To determine (1) whether the fine-scale clay drapes have a significant effect on the measured concentrations and (2) whether application of multiple-point geostatistics can improve interpretation of tracer tests in media with complex geological heterogeneity, this tracer test is analyzed with a local three-dimensional ground-water flow and transport model in which fine-scale sedimentary heterogeneity is modeled using multiple-point geostatistics. To reduce memory needs and calculation time for the multiple-point geostatistical simulation step, this study uses the technique of direct multiple-point geostatistical simulation of edge properties. Instead of simulating pixel values, model cell edge properties indicating the presence of irregularly shaped
\end{abstract}

\footnotetext{
M. Huysmans $(\varangle) \cdot$ E. Cochet · M. Possemiers · B. Ronchi · K. Lauriks · O. Batelaan · A. Dassargues

Department of Earth and Environmental Sciences, KU Leuven, Celestijnenlaan 200 E, 3001 Heverlee, Belgium

e-mail: marijke.huysmans@ees.kuleuven.be

M. Huysmans · O. Batelaan

Department of Hydrology and Hydraulic Engineering, Vrije Universiteit Brussel, Pleinlaan 2, 1050 Brussels, Belgium

P. Orban · A. Dassargues

Hydrogeology and Environmental Geology, Department of Architecture, Geology, Environment, and Civil Engineering (ArGEnCo), Université de Liège, B.52/3 Sart-Tilman, 4000 Liège, Belgium

O. Batelaan

School of the Environment, Flinders University, GPO Box 2100, Adelaide 5001, Australia
} 
surfaces are simulated using multiple-point geostatistical simulations. Results of a sensitivity analysis show under which conditions clay drapes have a significant effect on the concentration distribution. Calibration of the model against measured concentrations from the tracer tests reduces the uncertainty on the clay-drape parameters. The calibrated model shows which features of the breakthrough curves can be attributed to the geological heterogeneity of the aquifer and which features are caused by other processes.

Keywords Multiple-point geostatistics · Training image · Groundwater - Sorption · Tracer test · Upscaling

\section{Introduction}

Many ground-water flow and solute transport modeling, laboratory and field studies have demonstrated the sensitivity of solute transport to fine-scale structural heterogeneities (Güven et al. 1985; Ptak and Teutsch 1994; Vereecken et al. 2000; Huysmans and Dassargues 2009; Ronayne et al. 2010). Clay drapes or mud drapes are a very specific type of fine-scale sedimentary heterogeneities. Clay drapes are thin continuous or discontinuous layers of low-permeability material that are often observed in different types of sedimentary deposits (Reineck and Singh 1973). They are usually only a few centimeters thick (Houthuys 1990; Stright 2006) but several studies indicate that they may significantly influence the spatial distribution of permeability and, consequently, subsurface flow (Ringrose et al. 1993; Willis and White 2000; Morton et al. 2002; Mikes 2006; Stright 2006; Li and Caers 2011; Huysmans and Dassargues 2012). The effect of these clay drapes on solute transport has been studied by a modeling approach (Huysmans and Dassargues 2009), but large-scale field tests for exploring the effect of clay-drape distribution and parameters on solute transport have not yet been performed. Additionally, the possible effects of heterogeneous sorption resulting from clay drapes has not been investigated before. Therefore a field-scale ground-water tracer test was performed in a deposit displaying a complex distribution of clay drapes. This test aims at quantifying the effect of the presence of clay drapes on measured concentration breakthrough curves. Monitoring and modeling solute transport in the presence of clay drapes also raises the question of the effect of sorption on transport in such an environment. Tracer tests are often modeled with advective-dispersive transport alone (Ronayne et al. 2010). Additionally, as far as environmental purposes are concerned (i.e. protection zones delineation around pumping wells), sorption or other processes creating a delay in solute arrival are often neglected (Rentier et al. 2002; Derouane and Dassargues 1998; Dassargues 1994). In other studies, a non-negligible effect of sorption is observed if clay minerals are present (Vereecken et al. 2000). The present study investigates whether sorption related to clay drapes is an important process. Also investigated is whether sorption can be modeled using uniform values or whether the spatial distribution of sorption parameters should be taken into account.

Incorporating the heterogeneity of hydraulic conductivity and sorption parameters induced by clay drapes in flow and transport models is a difficult task. Clay 
drapes are thin and may display complex shapes and spatial distributions. Multiplepoint geostatistics is a technique that has proven to be very suitable for simulating the spatial distribution of complex sedimentary structures (Strebelle 2000, 2002; Caers and Zhang 2004; Hu and Chugunova 2008; Huysmans and Dassargues 2009; Comunian et al. 2011; dell'Arciprete et al. 2012). In the field of ground-water hydrology, application of multiple-point geostatistics for simulating the geometry and properties of geobodies or hydrofacies in heterogeneous media has become an active research topic in recent years. Several recent studies apply the method to synthetic cases (Feyen and Caers 2006) or use multiple-point geostatistics to build realistic (hydro)geological models based on field observations on geological outcrops and $\operatorname{logs}$ (Ronayne et al. 2010; Huysmans and Dassargues 2009; Bayer et al. 2011; Comunian et al. 2011; Le Coz et al. 2011; dell'Arciprete et al. 2012). For largescale three-dimensional grids multiple-point geostatistics may be computationally very intensive. Several studies therefore focus on improved implementations of the multiple-point statistics techniques to make the algorithms more powerful and computationally efficient (Mariethoz et al. 2010; Huysmans and Dassargues 2011; Straubhaar et al. 2011; Comunian et al. 2012). In the present study, multiple-point geostatistics is used to simulate heterogeneity of hydraulic conductivity and sorption parameters in a geologically consistent way, taking the observed spatial distribution of clay drapes into account. A fine-scale heterogeneous model with a geologically realistic distribution of clay drapes is built. The calculated breakthrough curves from this model with clay drapes are compared with the measured breakthrough curves and the calculated breakthrough curves from a more simple homogeneous model. In this way, this study will show whether multiple-point geostatistics can improve the interpretation of tracer tests in media with complex clay-drape distributions. This paper is organized as follows. First, the field tracer test is described. Then, the modeling approach and the multiple-point geostatistical simulation procedure are explained. Afterwards, the resulting breakthrough curves and the modeling results including calibration and sensitivity analyses are shown and finally discussion and conclusions are presented.

\section{Field Tracer Test}

A field tracer test was executed at the drinking water well field Huiskens in KorbeekLo (Belgium) operated by the Belgian water company De Watergroep. The test site is situated approximately $3 \mathrm{~km}$ southeast of the city of Leuven (Fig. 1). A site specific geological profile was established on the basis of 15 local drillings with a depth between 20 and $28 \mathrm{~m}$ (Fig. 2). Three different geological layers are distinguished in this geological profile. The upper unit, six to eight meters thick, corresponds to Quaternary deposits consisting of coarse sands with boulders and cemented concretions and dark brown to black peat and loam. Below the Quaternary deposits, MiddleEocene Brussels Sands with a varying thickness between 12 and $20 \mathrm{~m}$ are found. The Brussels Sands formation is a major ground-water reservoir in Belgium. The sands are deposited as a tidal sandbar deposit, resulting in a complex geological heterogeneity which is extensively described in Houthuys (1990), Huysmans et al. (2008), 


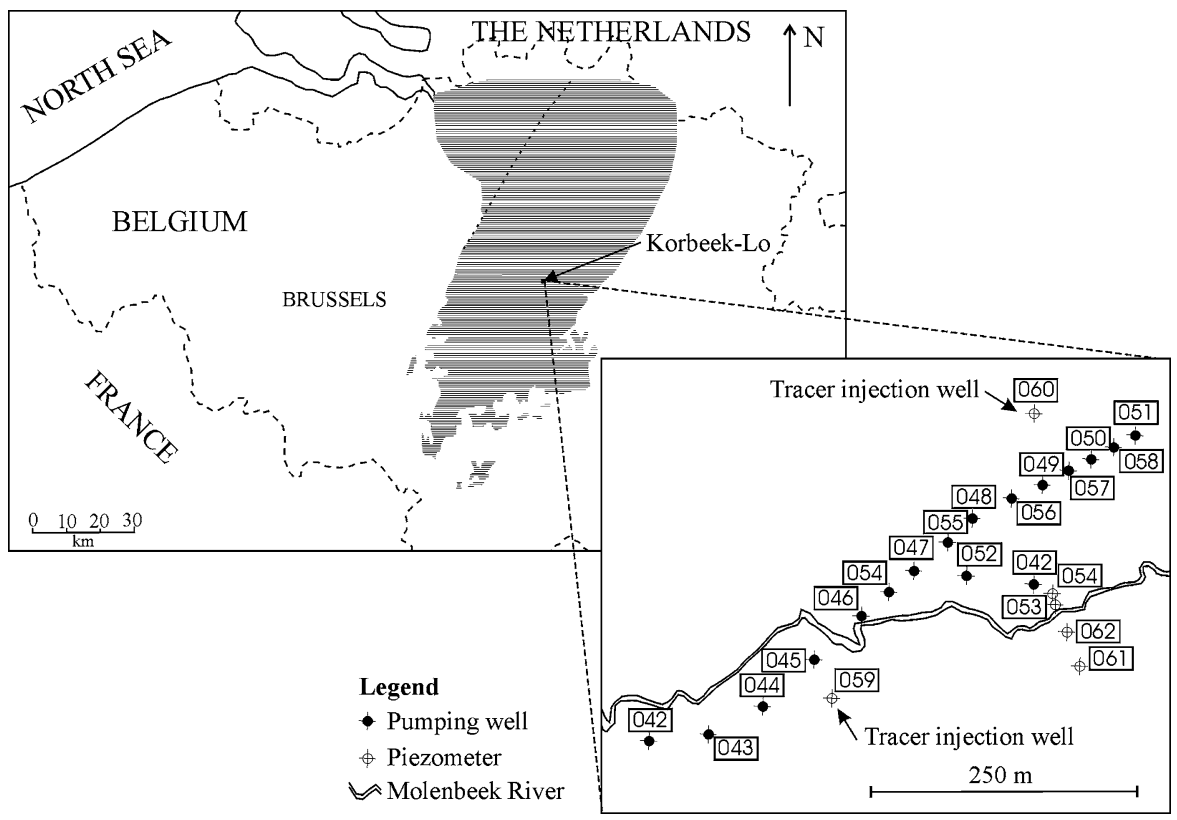

Fig. 1 Map of Belgium showing Brussels Sands outcrop and subcrop area (shaded part) modified after Houthuys (1990) and inset showing tracer test site map of the drinking water well field Huiskens in Korbeek-Lo (Belgium)

SW

NE

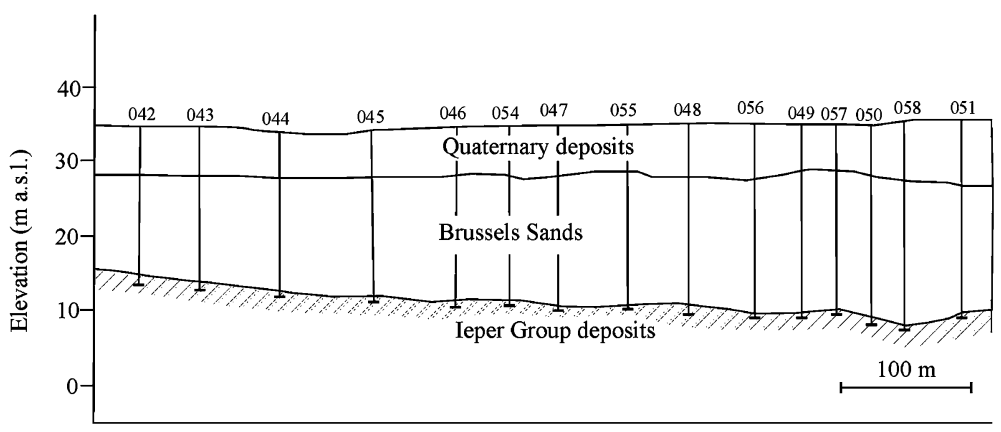

Fig. 2 Site specific geological profile

Houthuys (2011) and Possemiers et al. (2012). A very typical feature of these sands is the abundant occurrence of clay drapes. Below the Brussels Sands, fine-grained, relatively impermeable Ieper deposits are found (Huysmans and Dassargues 2006). On the test site, ground water is pumped from 17 pumping wells and monitored in two piezometers. The average ground-water production rate during the tracer test period was about $2400 \mathrm{~m}^{3} /$ day.

Sodium naphthionate was injected into the ground water in the two on-site piezometers (wells 59 and 60b) on April 6th 2011. Sodium naphthionate $\left(\mathrm{C}_{10} \mathrm{H}_{8}\right.$ 
$\mathrm{NNaO}_{3} \mathrm{~S}$ ) is a colorless fluorescent tracer with a detection limit of $0.2 \mathrm{mg} / \mathrm{m}^{3}$ under optimal conditions (Leibundgut et al. 2009). In piezometer 59, with a screened interval extending from 8 to $12 \mathrm{~m}$ below ground surface, $2 \mathrm{~kg}$ of sodium naphthionate diluted in 201 of water was injected followed by a native water injection of 701 during 15 minutes. In piezometer 60b with a depth of approximately $5 \mathrm{~m}, 2.45 \mathrm{~kg}$ of sodium naphthionate diluted in 201 of water was injected. Groundwater was sampled automatically in five ground-water abstraction wells (wells 44, 45, 49, 56 and 57 in Fig. 1) at a depth of approximately 9 m, from April 2011 until July 2011, using automatic water samplers (Teledyne ISCO 6712 Full-Size Portable Sampler). Samples were taken every hour in the beginning of the monitoring period and sampling frequency decreased to one sample per day towards the end of the 86-day long monitoring period. All monitoring wells have screens in the permeable Brussels Sands with screened intervals whose length varies between 14 and $17 \mathrm{~m}$. Wells 49 and 57 have an additional limited one-meter-long screen in the Quaternary deposits. The well bottoms correspond largely with the bottom of the permeable Brussels Sands. Sodium naphthionate concentrations were measured in 1034 ground-water samples by fluorescence spectroscopy using the HITACHI F-2500 spectrofluorometer with optimal wavelengths for excitation and emission ( 320 and $415 \mathrm{~nm}$, respectively). This resulted in measured concentration breakthrough curves versus time for the five observation wells.

\section{Modeling Approach}

A two-step nested modeling approach was applied. First, a large-scale model with layers of uniform flow and transport properties was built and calibrated on the combined dataset of measured heads in 59 observation wells and 1034 measured naphthionate concentrations during the tracer test in five wells. Second, a fine-grid model with heterogeneous hydraulic conductivity and distribution coefficient was run using the calculated heads from the large-scale model as boundary conditions. The assumptions and characteristics of both models are summarized in Table 1. Nested models can have different degrees of coupling. The models in this work were only loosely coupled by assigning calculated heads from the larger model as a Dirichlet boundary condition on the vertical boundaries of the smaller model. Other approaches are characterized by a higher degree of coupling to ensure continuity of fluxes and hydraulic

Table 1 Assumptions and characteristics of the large-scale and fine-scale model

\begin{tabular}{lll}
\hline & Large-scale model & Fine-scale model \\
\hline Size & $11.5 \mathrm{~km}$ by $8.1 \mathrm{~km}$ by $78 \mathrm{~m}$ & $150 \mathrm{~m}$ by $150 \mathrm{~m}$ by $24.5 \mathrm{~m}$ \\
Grid cell size & $1-100 \mathrm{~m}$ & $0.3-9 \mathrm{~m}$ \\
Hydraulic conductivity & Homogeneous per layer & Heterogeneous \\
Distribution coefficient & Homogeneous per layer & Heterogeneous \\
Clay drapes & Not included & Explicitly included \\
Calibration data & 59 head measurements and 1034 & 61 concentration measurements \\
& concentration measurements & \\
\hline
\end{tabular}


heads at the contact of the two grids, for example Giudici et al. (2001), Mehl and Hill (2002), Romano et al. (2002), Keating et al. (2003) and Mehl et al. (2006).

\subsection{Calibration of Large-Scale Flow and Transport Model}

The large-scale transient flow and transport model is based on a general stationary ground-water flow Modflow model from Ongena (2008). It is a three-dimensional model of $11.5 \mathrm{~km}$ by $8.1 \mathrm{~km}$ with a total thickness varying between 11 and $78 \mathrm{~m}$ (Fig. 3). The model consists of 205 rows and 269 columns. The largest grid cell dimension is $100 \mathrm{~m}$. Four different pumping well fields are included in the model. Progressive grid refinement occurs around all pumping wells where the side length of grid cells is $20 \mathrm{~m}$, and around the injection and monitoring wells used for the tracer test where grid cells are refined to dimensions of $1 \mathrm{~m}$ by $1 \mathrm{~m}$. The numerical model consists of three model layers representing the Quaternary deposits (upper layer) and the Brussels Sands (middle and lower layer). The top of the Ieper Clay deposits represent the impermeable bottom of the model due to the low permeability of this deposit. The Dijle River constitutes the west boundary of the model (Fig. 3). The northern model boundary is considered an impermeable boundary since dominant regional ground-water flow is parallel to this boundary. East and south boundaries are prescribed head boundaries deduced from nearby hydraulic head measurements. Aquifer recharge is dependent on land use and varies between 150 and $295 \mathrm{~mm} / \mathrm{year}$ based on a WetSpass simulation (Batelaan and De Smedt 2007). In the model 93 pumping wells are included using the Modflow well package. Three small rivers are incorporated using the Modflow river package and several ponds are inserted in the model using the general head boundary package. Conductance values for the rivers and ponds were calibrated by Ongena (2008) and are not further adjusted in the present study. Initial heads are taken from the stationary ground-water flow model from Ongena (2008) calibrated on long-term average measured heads. The differential equations describing ground-water flow were solved by Modflow (McDonald and Harbaugh 1988), a block-centered finite-difference method-based software package.

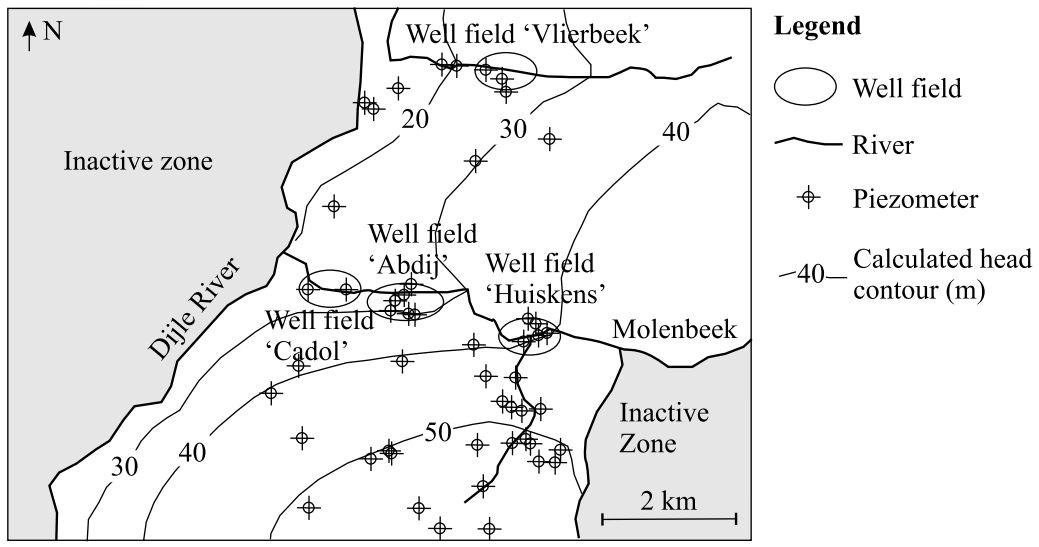

Fig. 3 Model area (white area) of large-scale model showing boundary conditions and piezometer locations 
Transport of sodium naphthionate was modeled as transport by advection, dispersion and sorption, and simulated with MT3DMS (Zheng and Wang 1999) using the high-order finite volume TVD solver. Visual Modflow, developed by Schlumberger Water Services, was used as pre- and post-processor. The maximum value of the numerical Courant number used for the determination of the time step for transport calculations is 0.75 . Calibration of hydraulic conductivity of the Quaternary deposits and the fine and coarse facies of the Brussels Sands was performed using PEST. Combined calibration using head and concentration measurements was applied. Time-averaged hydraulic head was available in 59 head observation wells and measured sodium naphthionate concentrations versus time from the tracer tests that were available in five wells. The weights for the head and the concentrations measurements were taken equal to the inverse of the squared average of measured values. Effective porosity, longitudinal dispersivity and distribution coefficient were calibrated using the measured sodium naphthionate concentrations. Transverse dispersivity was taken one order of magnitude smaller than longitudinal dispersivity (Zheng and Bennett 1995).

\subsection{Fine-Scale Flow and Transport Modeling with Heterogeneous Hydraulic Conductivity and Sorption}

The size and resolution of the large-scale model are too large to incorporate heterogeneity of hydraulic conductivity and sorption parameters related to the clay-drape presence. Therefore a local fine-scale fine-grid flow and transport model was built. This model is a $150 \mathrm{~m}$ by $150 \mathrm{~m}$ by $24.5 \mathrm{~m}$ three-dimensional model in which submeter scale clay drapes are incorporated in a manner consistent with local field data. In the inner central zone of the model where all injection and observation wells are situated, a very small grid cell size of $0.3 \mathrm{~m} \times 3 \mathrm{~m} \times 0.3 \mathrm{~m}$ is adopted so that individual clay drapes can be explicitly incorporated in the model in this zone. The spacing along the $\mathrm{y}$ direction is ten times greater than along the $x$ and $z$ directions since the sedimentary structures are assumed to be continuous along that direction (Sect. 3.2.1). Clay drape occurrence was simulated in this fine-scale model using multiple-point geostatistics. The next sections describe the details of this procedure which consists of the following steps. First, a field-based training image of clay-drape occurrence was constructed. Secondly, this training image was upscaled by converting from a pixel representation to an edge representation of the clay drapes. Next, this upscaled training image was used as and input image to SNESIM to simulate claydrape occurrence. This simulated field was translated into a spatially variable field of heterogeneous hydraulic conductivity and distribution coefficient to be used as input in the fine-scale flow and transport model.

\subsubsection{Training Image Construction}

A training image depicting spatial patterns of clay-drape occurrence was constructed based on in situ mapping. The Brussels Sands outcrops in a nearby quarry were used as an analog for the Brussels Sands found in the subsurface at the tracer test site. This outcrop of approximately $1200 \mathrm{~m}^{2}$ was mapped in detail with regards to the 

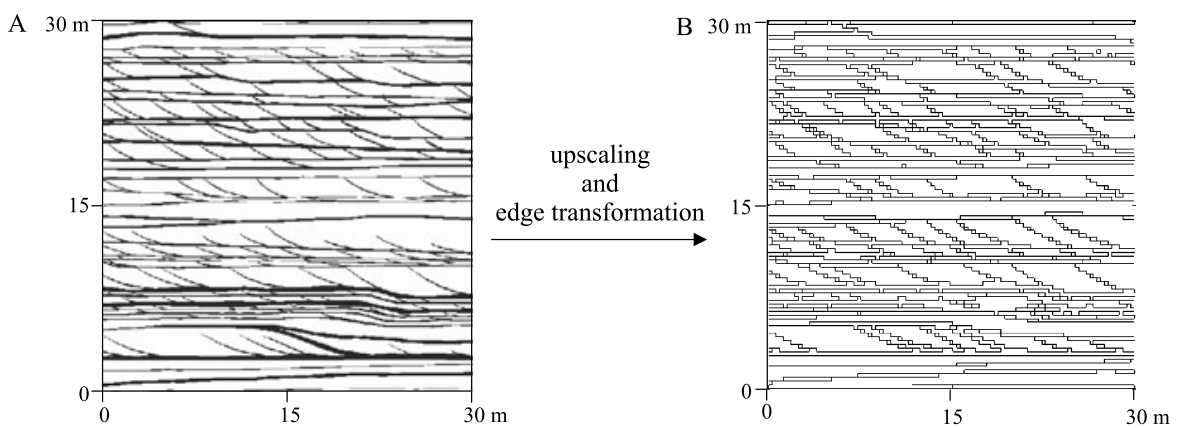

Fig. 4 (a) Vertical two-dimensional training image of $30 \mathrm{~m}$ by $30 \mathrm{~m}$ in NNE direction: sand facies (white), clay-rich facies (black) modified from Huysmans and Dassargues (2009) and (b) the corresponding edge training image modified from Huysmans and Dassargues (2011)

spatial distribution of sedimentary structures and permeability in Huysmans et al. (2008). A two-dimensional fine-scale training image along the NNE-direction was constructed based on this field mapping. This training image shows an alternation of sand-rich and clay-rich zones (Fig. 4). In the third dimension perpendicular to the two-dimensional training image used in this study, layering and clay drapes are very continuous. While the NNE-oriented faces of the outcrops display complex patterns of cross-bedding and inclined mud drapes, the perpendicular faces mainly show continuous horizontal layering. Therefore all layers and sedimentary structures are assumed to be continuous in that direction. The incorporation of three-dimensional simulations based on several two-dimensional training images in different directions following the approaches discussed in Comunian et al. (2012) could be interesting future work. More details about construction of this training image can be found in Huysmans and Dassargues (2009). In the next section, multiple-point statistics are inferred from this training image to simulate realizations of clay-drape occurrence to be used as input for the local ground-water flow model.

\subsubsection{Clay Drapes Simulation Using Multiple-Point Geostatistical Simulation of Edge Properties}

In multiple-point geostatistics, patterns are inferred from the training image and reproduced in the simulation domain (Guardiano and Srivastava 1993; Strebelle and Journel 2001; Caers and Zhang 2004). More information about the theory behind multiple-point geostatistics can be found in Strebelle (2000) and Strebelle (2002). Description of the different multiple-point algorithms can be found in the following papers: SNESIM (Strebelle 2002; Liu 2006), FILTERSIM (Zhang et al. 2006; Wu et al. 2008), SIMPAT (Arpat and Caers 2007), HOSIM (Mustapha and Dimitrakopoulos 2010) and the Direct Sampling method (Mariethoz et al. 2010). In this study, the technique of direct multiple-point geostatistical simulation of edge properties (Huysmans and Dassargues 2011) is used to incorporate clay drapes showing patterns similar to the training image of Fig. 4 in the ground-water flow and transport model. This technique was designed to simulate thin complex surfaces such as clay drapes with a smaller CPU and RAM demand than the conventional multiple-point 


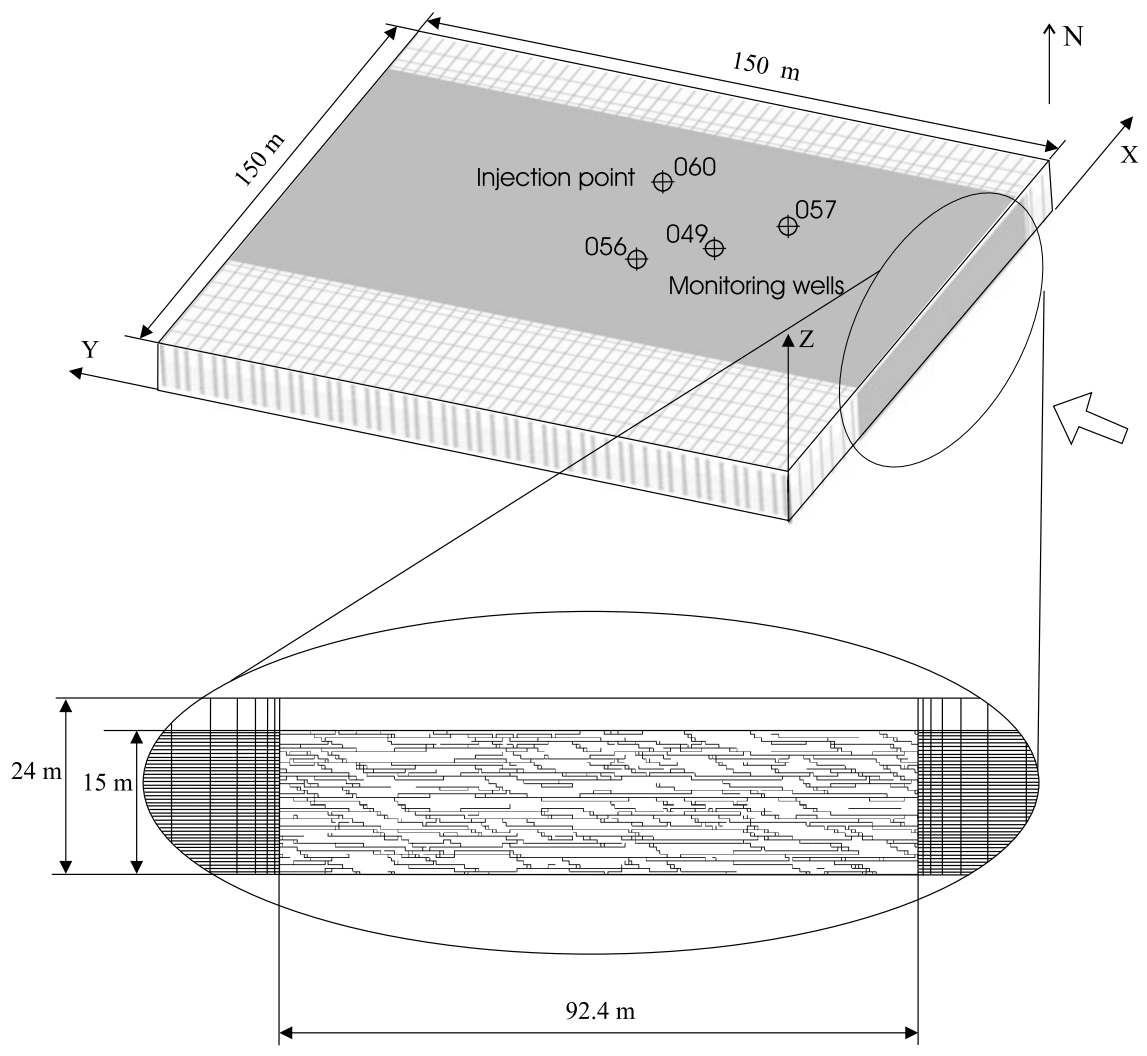

Fig. 5 Fine-scale groundwater flow and transport model grid and edge realization

statistical methods. Instead of pixel values, edge properties indicating the presence of irregularly shaped surfaces are simulated using multiple-point geostatistical simulation algorithms. The training image is upscaled by representing clay drapes as edge properties between cells instead of representing them as objects consisting of several cells. The concept of the edge of a flow model and the associated edge properties was introduced in the work of Stright (2006) as an additional variable. The edge properties are assigned to the cell faces. The cell property used in this study is the presence of clay drapes along cell faces. More details about the method can be found in Huysmans and Dassargues (2011). The fine-scale training image has a grid cell size of $0.05 \mathrm{~m}$ and represents the clay drapes as consisting of pixels with a different pixel value than the background material. The upscaled edge-based training image has a grid cell size of $0.30 \mathrm{~m}$ and represents the clay drapes as edge properties that indicate the presence of clay drapes along the edges of all grid cells. The upscaled $30 \mathrm{~m}$ by $30 \mathrm{~m}$ training image is used as input to SNESIM from SGeMS (Remy et al. 2009) in order to simulate a clay-drape realization to be imported in the inner central zone of the model where individual clay drapes are incorporated. Vertical two-dimensional realizations of $92.4 \mathrm{~m}$ by $15 \mathrm{~m}$ are generated. Figure 5 shows the random clay-drape realization that is incorporated in the ground-water flow and transport model. 


\subsubsection{Fine-Scale Ground-Water Flow and Transport Model}

The ground-water flow and transport model is a three-dimensional local model of $150 \mathrm{~m} \times 150 \mathrm{~m} \times 24.5 \mathrm{~m}$, including the injection and observation wells for which a significant sodium naphthionate concentration was measured (Fig. 5). The fine-scale model is oriented along the $\mathrm{N} 22.5^{\circ} \mathrm{E}$ direction which is parallel to the direction of the main geological structures including most clay drapes. The top of the Ieper Clay deposits represents the impermeable bottom of the model due to the low permeability of this unit (Huysmans and Dassargues 2006). Constant hydraulic heads are assigned to all vertical boundaries with values equal to the computed values from the large-scale ground-water flow model. In the centre of the model where all injection and observation wells are situated, a very small grid cell size of $0.3 \mathrm{~m} \times 3 \mathrm{~m} \times 0.3 \mathrm{~m}$ is adopted so that individual clay drapes can be explicitly incorporated in the model in this zone. The model consists of $323 \times 50 \times 52=839,800$ cells. Initial values for hydraulic conductivity, recharge, effective porosity and dispersivity are adopted from the largescale calibrated model. The mass of injected sodium naphthionate for each injection well is incorporated as specified flux conditions. The pre- and post-processor Processing Modflow for Windows (PMWIN) (Chiang and Kinzelbach 2001) for MODFLOW and MT3DMS was used for the flow and transport modeling.

The realization of clay-drape presence can be imported into the ground-water flow code PMWIN using the Horizontal-Flow Barrier (HBF) package and the vertical leakance (VCONT) array (Chiang and Kinzelbach 2001). The HBF package simulates thin vertical low-permeability geological features, which impede horizontal ground-water flow. They are situated on the boundaries between pairs of adjacent cells in the finite-difference grid (Hsieh and Freckleton 1993). A horizontal-flow barrier is defined by assigning the barrier direction, which indicates the cell face where the barrier is located, and the clay-drape parameter, which is the barrier hydraulic conductivity divided by the thickness of the barrier (Chiang and Kinzelbach 2001). Horizontal edges are inserted into MODFLOW by adapting vertical leakance (VCONT array) between two model layers. In case a horizontal edge is present in a model cell, the edge is inserted in the model as a semi-confining unit. Initially, it is assumed that all clay drapes in the ground-water flow model have a thickness of $0.02 \mathrm{~m}$ and a hydraulic conductivity of $0.2 \mathrm{~m} / \mathrm{d}$ (Huysmans and Dassargues 2012). The relation between sorption and clay-drape presence is more complicated than the relation between hydraulic conductivity and clay drapes. Linear sorption can be described using the distribution coefficient or retardation coefficient

$$
\begin{aligned}
S & =K_{d} C, \\
R & =1+\frac{\rho}{n} K_{d},
\end{aligned}
$$

where $S$ is the adsorbed solute concentration $[\mathrm{mg} / \mathrm{kg}], K_{d}$ is the distribution coefficient $\left[\mathrm{m}^{3} / \mathrm{kg}\right], C$ is the solute concentration $\left[\mathrm{mg} / \mathrm{m}^{3}\right], R$ is the retardation coefficient $[-], \rho$ is the dry bulk mass density of soil $\left[\mathrm{kg} / \mathrm{m}^{3}\right]$ and $n[-]$ is the porosity. Some authors report weak negative correlations between distribution coefficient and hydraulic conductivity (Robin et al. 1991), others report positive correlations between distribution coefficient and log transformed values of clay content (Vereecken et al. 
2000). In the case of the Brussels Sands, it is expected that clay drapes increase sorption of naphthionate. Therefore, a heterogeneous distribution coefficient was assigned cell-by-cell so that cells bounded by clay drapes are assigned a higher distribution coefficient than cells without clay drapes. Initially, a distribution coefficient of $2.9 \times 10^{-9} \mathrm{~m}^{3} / \mathrm{kg}$ was assigned to the cells bounded by clay drapes while no sorption was assumed in the other cells. The value of the distribution coefficient was later adapted during sensitivity analysis and calibration. For computational reasons, the fine-scale model is ran for only one realization of clay-drape occurrence. One model run on an Intel Quad-Core $2.20 \mathrm{GHz}$ machine with $8 \mathrm{~GB}$ RAM took several days. In order to quantify the effect of clay-drape parameters on tracer breakthrough curves, a sensitivity analysis was carried out. The following parameters were subjected to a sensitivity analysis: clay-drape conductivity, clay-drape thickness and distribution coefficient.

\section{Results}

\subsection{Tracer Breakthrough Curves}

Figure 6a shows measured sodium naphthionate concentrations versus time in the five monitoring wells. In three out of the five wells, significant concentrations are observed. First arrivals are observed approximately 92 hours after injection. Highest concentrations in the three wells are measured at, respectively, 23, 24, and 30 days after injection. The highest measured concentration in this tracer experiment is $135 \mathrm{ppb}$. The measured concentrations show a particular behavior versus time. Instead of a gradually increasing concentration followed by a gradually decreasing concentration, alternating high and low concentrations appear. The tracer test was performed in actual exploitation conditions with irregular and automatic starting and stopping of the pumps. Comparison of the measured concentrations with recorded pumping discharges versus time in the abstraction wells where concentrations are measured shows that the highest concentrations are measured when the pumps are shut down. On the contrary, very low sodium naphthionate concentrations are measured when pumping at a high discharge. The correlation coefficient between sodium naphthionate concentration and pumping discharge is -0.51 . It seems that some kind of mixing or dilution occurs when pumping at a high rate, possibly because at that time ground-water is also pumped from other more shallow thin sand layers in which some pumping wells are also screened. Because we are interested in concentrations in the Brussels Sands, the concentrations that were measured at high pumping discharge were removed from the dataset for the remainder of this analysis. Also the wells where no significant concentrations were measured (piezometers 44 and 45) were removed from the dataset for the fine-scale modeling. This was done because the fine-scale models could not be made large enough to capture both tracer injections. Since the injection in well 59 did not result in significant concentrations in any measurement well, only the injection in well 60 with monitoring points 49,56 and 57 was modeled with a fine-scale model. Figure $6 \mathrm{~b}$ shows the concentration measurements that are used for further comparison with modeling results. Although these concentration values show a more gradual 

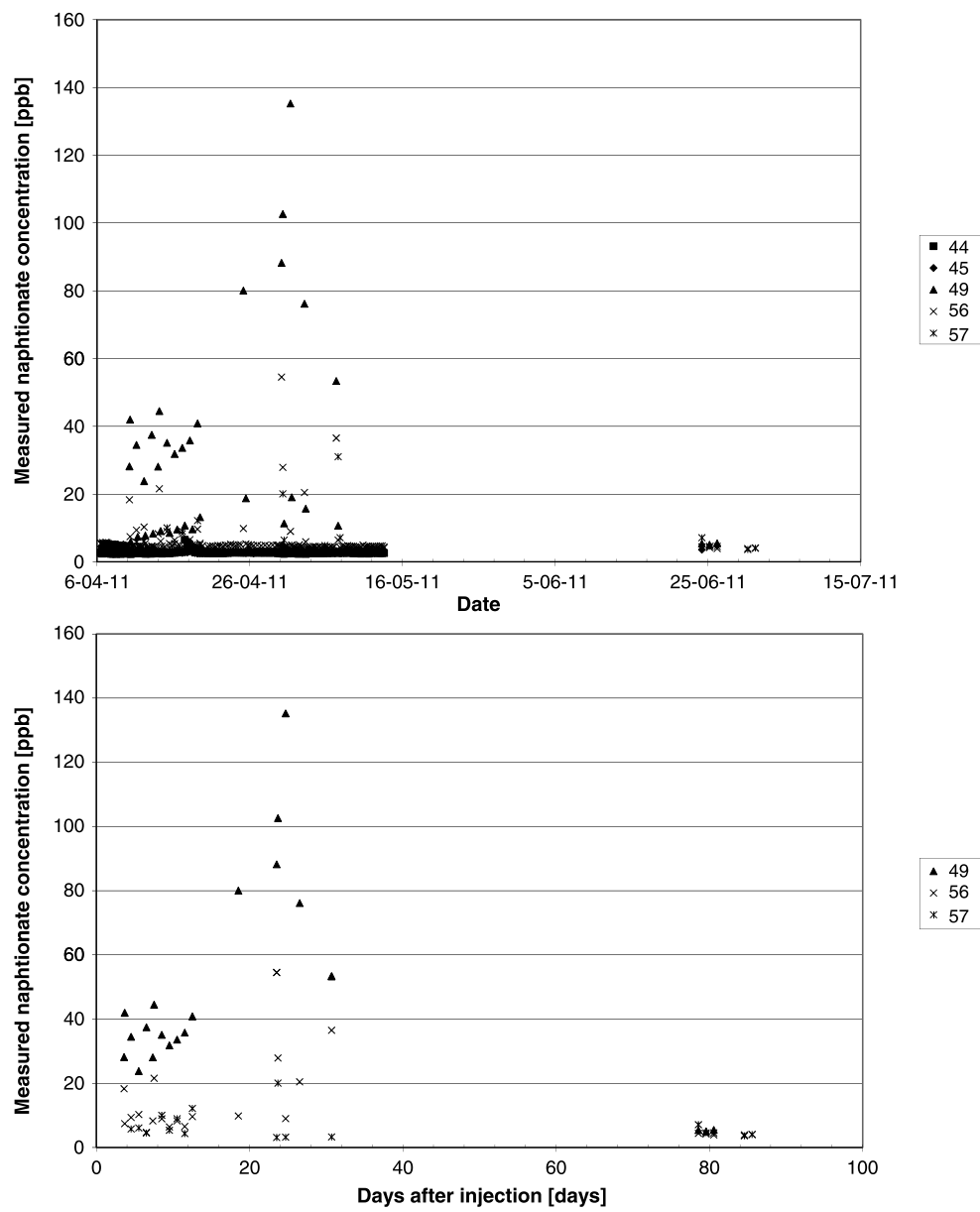

Fig. 6 (a) Raw and (b) filtered measured sodium naphthionate breakthrough curves

evolution in time than the raw dataset, some non-smooth behavior is still observed. Further modeling in the next sections will investigate whether this non-smooth behavior can be attributed to local heterogeneity.

\subsection{Calibration of Large-Scale Flow and Transport Model}

The large-scale flow and transport model was calibrated using PEST. Combined calibration using head and concentrations measurements was applied. Average hydraulic head was available in 59 head observation wells and 1034 measured naphthionate concentrations from five wells were available from the tracer test. Best calibration results were obtained for the following parameter values. Hydraulic conductivity (K) in the Quaternary deposits was set to an isotropic value of $3 \mathrm{~m} /$ day. Hydraulic conductivity in the Brussels Sands was set to $18.29 \mathrm{~m} /$ day in the horizontal direction 
Fig. 7 Calculated versus observed average heads $(\mathrm{m})$ for the large-scale model

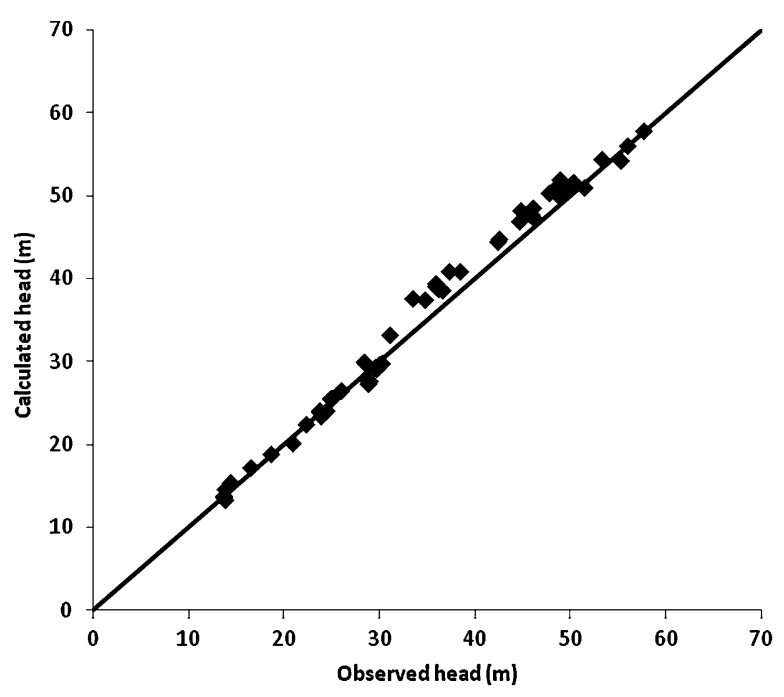

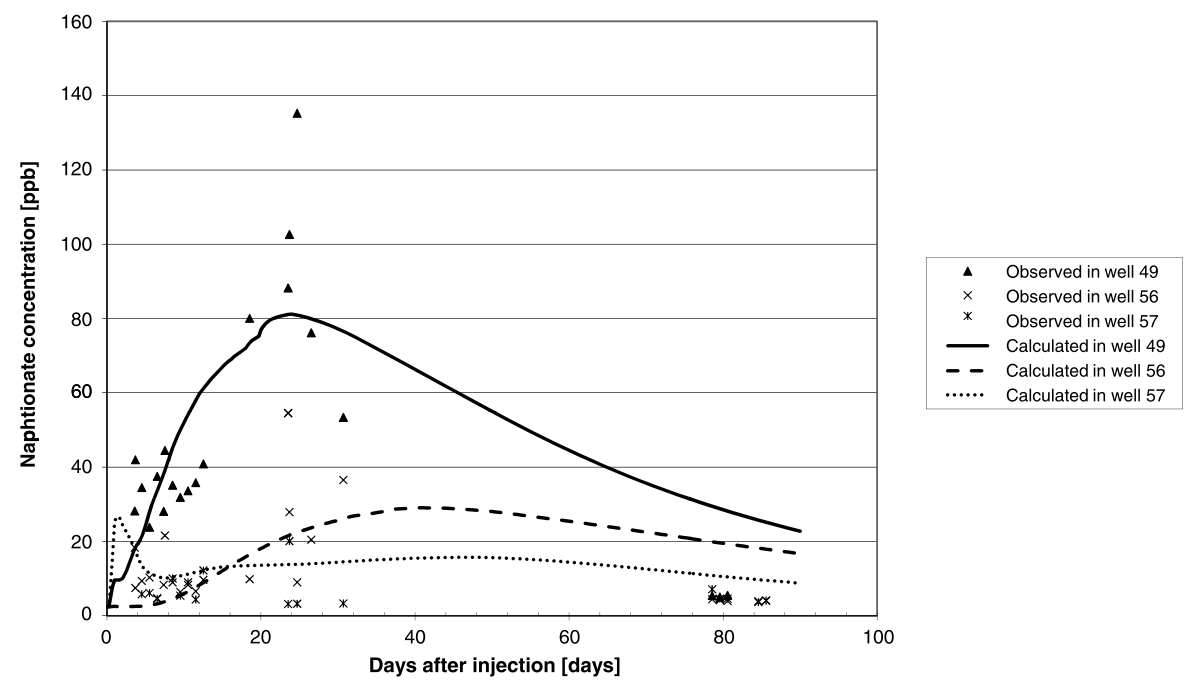

Fig. 8 Calculated and observed sodium naphthionate concentrations (ppb) for the large-scale model

and $3.9 \mathrm{~m} /$ day in the vertical direction. Effective porosity was set to $5 \%$. Longitudinal dispersivity was set to $15 \mathrm{~m}$ and the uniform distribution coefficient was set to $3.5 \times 10^{-9} \mathrm{~m}^{3} / \mathrm{kg}$. Figure 7 shows measured versus calculated heads $(\mathrm{RMS}=1.7 \mathrm{~m})$. Figure 8 shows measured and calculated concentrations versus time. With this largescale model with homogeneous layers, not all concentration variations in time could be reproduced. The parameters and calculated heads from the large-scale flow and transport model were used as input parameters and boundary conditions for the finescale heterogeneous model. 


\subsection{Sensitivity Analysis of Heterogeneous K and Sorption}

The fine-scale heterogeneous flow and transport model was run with different claydrape properties. First, the effect of sorption related to clay-drape presence was investigated. Figure 9 shows calculated breakthrough curves of the fine-scale model with and without heterogeneous sorption. In the model with heterogeneous sorption, the distribution coefficient of cells containing clay drapes was set to $2.9 \times 10^{-9} \mathrm{~m}^{3} / \mathrm{kg}$. Clay drape sorption seems to have similar effects on the breakthrough curves as uniform homogeneous sorption: peak tracer concentration timing shifts to later times (from 10 days to 25 days) and a much heavier late-time tail is observed when claydrape sorption is incorporated compared to a simulation without sorption. Second, the effect of clay-drape hydraulic conductivity and thickness on the calculated breakthrough curves was investigated. Figure 10 shows calculated breakthrough curves for a clay-drape parameter (defined as conductivity of clay drape divided by thickness of clay drape) of $20 \mathrm{day}^{-1}$ and $2 \mathrm{day}^{-1}$. Lower clay-drape permeability results in a later tracer concentration peak (32 days instead of 24 days) and lower maximum concentrations (130 ppb instead $175 \mathrm{ppb}$ ).

Fig. 9 Calculated breakthrough curves without (solid line) and with (dashed line) heterogeneous sorption

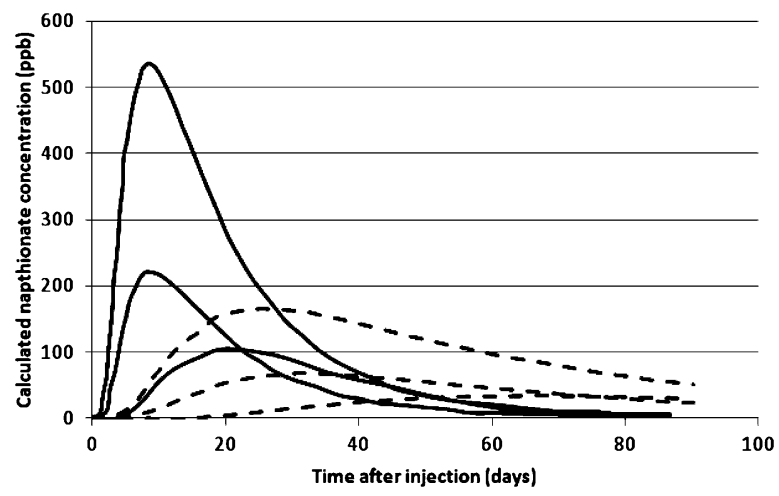

Fig. 10 Calculated breakthrough curves for clay-drape parameters of 20 day $^{-1}$ (solid line) and 2 day $^{-1}$ (dashed line)

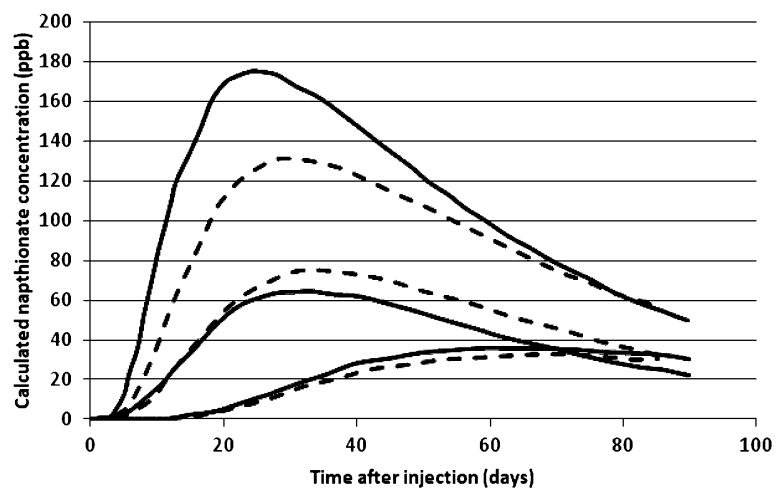




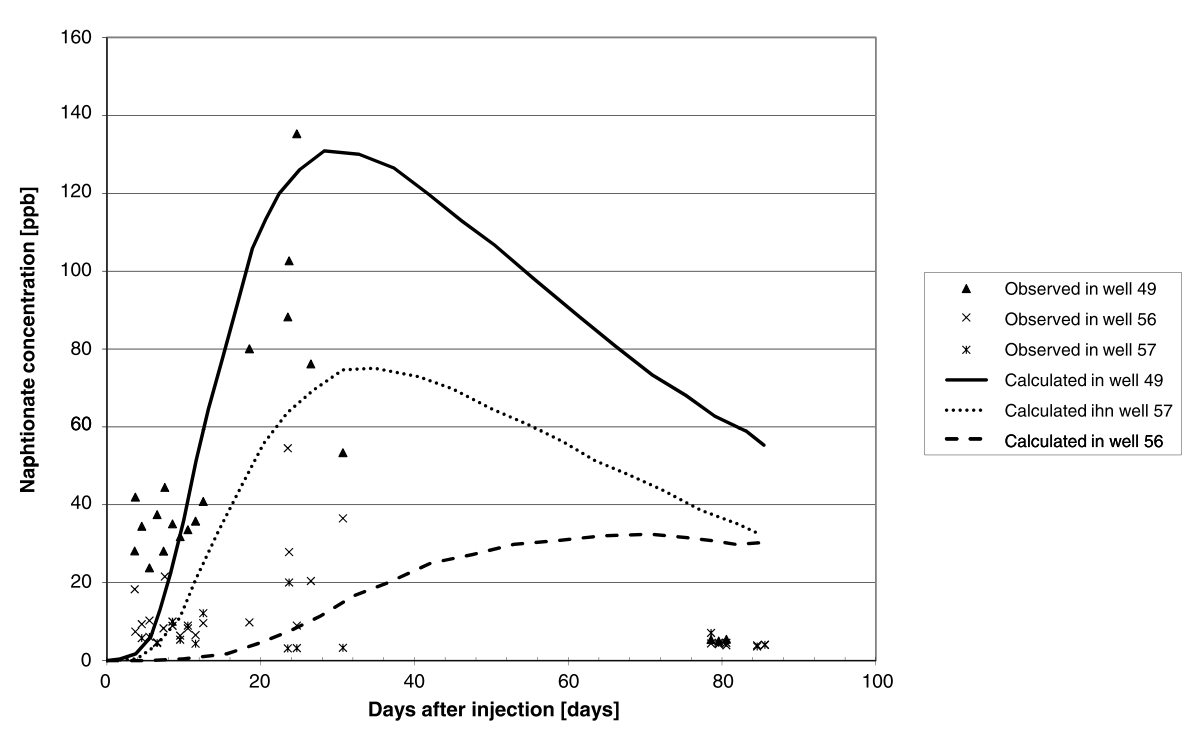

Fig. 11 Observed and calculated sodium naphthionate breakthrough curves from the fine-scale heterogeneous model

\subsection{Calibration of Fine-Scale Flow and Transport Model}

Clay drape permeability, thickness and distribution coefficients were calibrated using the measured sodium naphthionate concentrations. The best fit was found for the following parameter values: clay-drape parameter equal to $2 \mathrm{day}^{-1}$ and distribution coefficient for cells containing clay drapes equal to $2.913 \times 10^{-9} \mathrm{~m}^{3} / \mathrm{kg}$. The model does succeed in reproducing peak timing and the order of magnitude of concentration but does not succeed in an accurate reproduction of all measured time-dependent variations in the breakthrough curves (Fig. 11). It also seems that the modeled breakthrough curves have a heavier late-time tail than the measured ones, although this is difficult to assess since no tracer measurements are available in a large time interval after the peak (32 to 76 days after injection).

\section{Discussion and Conclusions}

A first aim of this study was to quantify the effect of the presence of clay drapes on measured concentration breakthrough curves. The sensitivity analysis of claydrape parameters has clearly shown the effect of clay-drape parameters on calculated breakthrough curves. Clay drapes with a lower hydraulic conductivity or a larger thickness result in later peak tracer concentration timing and lower maximum concentrations. This confirms the finding of several earlier studies (Ringrose et al. 1993; Willis and White 2000; Morton et al. 2002; Mikes 2006; Stright 2006; Huysmans and Dassargues 2009; Li and Caers 2011; Huysmans and Dassargues 2012) that clay drapes that are only a few centimeters thick can significantly influence subsurface flow and solute transport. This study also aimed to investigate the role of sorption 
in the presence of clay drapes. Sensitivity analysis shows that peak tracer concentration timing shifts to later times and that a much heavier late-time tail is observed when clay-drape sorption is incorporated. Both the large-scale model and the heterogeneous fine-scale model show that sorption should be included to reproduce peak concentration timing and the order of magnitude of tracer breakthrough concentrations. This confirms the positive correlation between distribution coefficient and clay content that was reported by Vereecken et al. (2000). In geological media with a significant amount of clay drapes, tracer tests can thus not be modeled accurately with only advective-dispersive transport.

This study also evaluated the application of multiple-point geostatistics for the interpretation of tracer tests in a medium with complex geological heterogeneity. It has been confirmed that multiple-point geostatistics is a suitable and efficient technique for simulating the spatial distribution of such complex structures. Even for simulating very fine-scale structures in a three-dimensional grid at field-scale, multiple-point simulations are very efficient. The computation time needed for simulating heterogeneity using SNESIM is only a fraction of the computation time needed to run the transport model. The main limitation of this approach is the computation time of the fine-scale flow and transport model. Incorporating very finescale clay drapes in a field-scale model results in a very large model with a relatively fine-grid cell size. The computational requirements for such models are often so high that these detailed complex models become impractical and this limits the possibilities for sensitivity analysis or calibration that require a large number of model runs. Recent developments in computational statistics applied to flow problems seem very promising for tackling these issues. Recent advances suggest that the amount of realizations can be significantly reduced by simulating a limited number of simple and complex models in a joint procedure and that more simple models can be used when models are designed for a specific purpose (Scheidt et al. 2011; Aydin and Caers 2013). Application of these new principles and techniques on flow and transport in clay-drape environments might be a very interesting path of further research.

Although very detailed field-based geological heterogeneity was incorporated in the modeling approach, not all variations observed in the measured breakthrough curves could be reproduced with the model. Additionally, the late-time tail behavior could not be reproduced satisfactorily. In this case, modeling the tracer test with a detailed heterogeneous model only slightly improved the fit of the breakthrough curves compared to a model with homogeneous hydraulic conductivity and sorption. It seems that not all features of the breakthrough curves can be attributed to the geological heterogeneity of the aquifer. The time-dependent variations in the breakthrough curves should be attributed to other processes, for example dissolution or mixing with water from other sand layers, variations of the pumping discharge rates or sampling issues. In order to use tracer test results for testing conceptualizations of geological heterogeneity in future tests, we recommend that the test should be executed on a site where pumping discharge can remain constant. Additionally, having multiple injection and sampling points is definitely needed for this kind of analysis. Interpretation of the tracer breakthrough curves would also be much more straightforward if all wells were only screened in one geological layer. 
Acknowledgements The authors wish to acknowledge the Fund for Scientific Research-Flanders (FWO) for providing a Postdoctoral Fellowship and a Research Grant to the first author. The authors wish to acknowledge De Watergroep (formerly known as VMW) for their permission for this test and their help. We thank the reviewers and guest editors for their constructive and helpful comments.

\section{References}

Arpat GB, Caers J (2007) Conditional simulation with patterns. Math Geol 39(2):177-203

Aydin O, Caers J (2013) Image transforms for determining fit-for-purpose complexity of geostatistical models in flow modeling. Comput Geosci 17(2):417-429

Batelaan O, De Smedt F (2007) GIS-based recharge estimation by coupling surface-subsurface water balances. J Hydrol 337(3-4):337-355

Bayer P, Huggenberger P, Renard P, Comunian A (2011) Three-dimensional high resolution fluvio-glacial aquifer analog, part 1: field study. J Hydrol 405(1-2):1-9

Caers J, Zhang T (2004) Multiple-point geostatistics: a quantitative vehicle for integrating geologic analogs into multiple reservoir models, in integration of outcrop and modern analog data in reservoir models. AAPG Mem 80:383-394

Chiang W, Kinzelbach W (2001) 3D-groundwater modeling with PMWIN. Springer, Berlin

Comunian A, Renard P, Straubhaar J, Bayer P (2011) Three-dimensional high resolution fluvio-glacial aquifer analog, part 2: geostatistical modeling. J Hydrol 405(1-2):10-23

Comunian A, Renard P, Straubhaar J (2012) 3D multiple-point statistics simulation using 2D training images. Comput Geosci 40:49-65

Dassargues A (1994) Applied methodology to delineate protection zones around pumping wells. J Environ Hydrol 2(2):3-10

dell'Arciprete D, Bersezio R, Felletti F, Giudici M, Comunian A, Renard P (2012) Comparison of three geostatistical methods for hydrofacies simulation: a test on alluvial sediments. Hydrogeol J 20:299_ 311

Derouane J, Dassargues A (1998) Delineation of groundwater protection zones based on tracer tests and transport modelling in alluvial sediments. Environ Geol 36(1-2):27-36

Feyen L, Caers J (2006) Quantifying geological uncertainty for f low and transport modeling in multimodal heterogeneous formations. Adv Water Resour 29(6):912-929

Giudici M, Parravicini G, Ponzini G, Romano E, Villa D (2001) Nested models to simulate groundwater flow at different scales. Geophys Res Abstr 3:2086

Guardiano F, Srivastava M (1993) Multivariate geostatistics: beyond bivariate moments. In: Soares A (ed) Geostatistics-Troia. Kluwer Academic, Dordrecht

Güven O, Falta RW, Molz FJ, Melville JG (1985) Analysis and interpretation of single-well tracer tests in stratified aquifers. Water Resour Res 21(5):676-684

Houthuys R (1990) Vergelijkende studie van de afzettingsstruktuur van getijdenzanden uit het Eoceen en van de huidige Vlaamse banken. Aardkundige mededelingen, vol 5. Leuven University Press, Leuven

Houthuys R (2011) A sedimentary model of the Brussels Sands, Eocene, Belgium. Geol Belg 14(1-2):5574

Hsieh PA, Freckleton JR (1993) Documentation of a computer program to simulate horizontal-flow barriers using the US geological survey's modular three-dimensional finite-difference ground water flow model. US geological survey open file report 92-477

Hu LY, Chugunova T (2008) Multiple-point geostatistics for modeling subsurface heterogeneity: a comprehensive review. Water Resour Res. doi:10.1029/2008WR006993

Huysmans M, Dassargues A (2006) Hydrogeological modeling of radionuclide transport in low permeability media: a comparison between Boom Clay and Ypresian Clay. Environ Geol 50(1):122-131

Huysmans M, Dassargues A (2009) Application of multiple-point geostatistics on modeling groundwater flow and transport in a cross-bedded aquifer. Hydrogeol J 17(8):1901-1911

Huysmans M, Dassargues A (2011) Direct multiple-point geostatistical simulation of edge properties for modelling thin irregularly-shaped surfaces. Math Geosci 43(5):521-536

Huysmans M, Dassargues A (2012) Modeling the effect of clay drapes on pumping test response in a cross-bedded aquifer using multiple-point geostatistics. J Hydrol 450(451):159-167

Huysmans M, Peeters L, Moermans G, Dassargues A (2008) Relating small-scale sedimentary structures and permeability in a cross-bedded aquifer. J Hydrol 36:41-51 
Keating EH, Vesselinov VV, Kwicklis E, Lu Z (2003) Coupling basin- and site-scale inverse models of the Espanola Aquifer. Ground Water 41:200-211

Le Coz M, Genthon P, Adler PM (2011) Multiple-point statistics for modeling facies heterogeneities in a porous medium: the Komadugu-Yobe Alluvium, Lake Chad basin. Math Geosci 43:861-878

Leibundgut C, Maloszewski P, Külls C (2009) Tracers in Hydrology. Wiley, Chichester. doi:10.1002/ 9780470747148

Li HM, Caers J (2011) Geological modelling and history matching of multi-scale flow barriers in channelized reservoirs: methodology and application. Pet Geosci 17(1):17-34

Liu Y (2006) Using the Snesim program for multiple-point statistical simulation. Comput Geosci 32(10):1544-1563

Mariethoz G, Renard P, Straubhaar J (2010) The direct sampling method to perform multiple-point geostatistical simulations. Water Resour Res. doi:10.1029/2008WR007621

McDonald MG, Harbaugh AW (1988) A modular three-dimensional finite-difference ground-water flow model. US Geol Surv Open-File Rep 83-875

Mehl SW, Hill MC (2002) Development and evaluation of a local grid refinement method for blockcentered finite-difference groundwater models using shared nodes. Adv Water Resour 25(5):497511

Mehl SW, Hill MC, Leake SA (2006) Comparison of local grid refinement methods for MODFLOW. Ground Water 44:792-796

Mikes D (2006) Sampling procedure for small-scale heterogeneities (crossbedding) for reservoir modeling. Mar Pet Geol 23(9-10):961-977

Morton K, Thomas S, Corbett P, Davies D (2002) Detailed analysis of probe permeameter and vertical inteference test permeability measurements in a heterogeneous reservoir. Pet Geosci 8:209-216

Mustapha H, Dimitrakopoulos R (2010) High-order stochastic simulation of complex spatially distributed natural phenomena. Math Geosci 42:457-485

Ongena D (2008) Een grondwaterstroming- en transportmodel ter hoogte van de VMW-waterwinningen langs de Molenbeek te Leuven (A groundwater flow and transport model around the VMW water well fields along the Molenbeek in Leuven). KULeuven master thesis, Leuven

Possemiers M, Huysmans M, Peeters L, Batelaan O, Dassargues A (2012) Relationship between sedimentary features and permeability at different scales in the Brussels Sands. Geol Belg 15(3):156-164

Ptak T, Teutsch G (1994) Forced and natural gradient tracer tests in a highly heterogeneous porous aquifer: Instrumentation and measurements. J Hydrol 159:79-104

Reineck H-E, Singh IB (1973) Depositional sedimentary environments: with reference to terrigenous clastics. Springer, Berlin

Remy N, Boucher A, Wu J (2009) Applied geostatistics with SGeMS—a user's guide. Cambridge University Press, New York

Rentier C, Brouyère S, Dassargues A (2002) Integrating geophysical and tracer test data for accurate solute transport modelling in heterogeneous porous media. In: Groundwater quality: natural and enhanced restoration of groundwater pollution. Proceedings of the groundwater quality 2001 conference held at Sheffield, June 2001. IAHS Publ, vol 275, pp 3-10

Ringrose PS, Sorbie KS, Corbett PWM, Jensen JL (1993) Immiscible flow behaviour in laminated and cross-bedded sandstones. J Pet Sci Eng 9(2):103-124

Robin MJL, Sudicky EA, Gillham RW, Kachanoski RG (1991) Spatial variability of strontium distribution coefficients and their correlation with hydraulic conductivity in the Canadian forces base borden aquifer. Water Resour Res 27(10):2619-2632

Romano E, Giudici M, Ponzini G (2002) Simulation of the interactions between well fields with nested models: a case study. Acta Univ Carol, Geol 46:637-640

Ronayne MJ, Gorelick SM, Zheng C (2010) Geological modelling of submeter scale heterogeneity and its influence on tracer transport in a fluvial aquifer. Water Resour Res. doi:10.1029/2010WR009348

Scheidt C, Caers J, Chen Y, Durlofsky LJ (2011) A multi-resolution workflow to generate high-resolution models constrained to dynamic data. Comput Geosci 15:545-563

Straubhaar J, Renard P, Mariethoz G, Froidevaux R, Besson O (2011) An improved parallel multiple-point algorithm using a list approach. Math Geosci 43(3):305-328

Strebelle S (2000) Sequential simulation drawing structures from training images. Doctoral dissertation, Stanford University

Strebelle S (2002) Conditional simulation of complex geological structures using multiple-point statistics. Math Geol 34:1-22

Strebelle S, Journel A (2001) Reservoir modeling using multiple point statistics: SPE 71324. In: 2001 SPE annual technical conference and exhibition, New Orleans, 30 September-3 October 2001 
Stright L (2006) Modeling, upscaling and history matching thin, irregularly-shaped flow barriers; a comprehensive approach for predicting reservoir connectivity. SPE paper 106528

Vereecken H, Döring U, Hardelauf H, Jaekel U, Hashagen U, Neuendorf O, Schwarze H, Seidemann R (2000) Analysis of solute transport in a heterogeneous aquifer: the Krauthausen field experiment. J Contam Hydrol 45(3-4):329-358

Willis BJ, White CD (2000) Quantitative outcrop data for flow simulation. J Sediment Res 70:788-802

Wu J, Boucher A, Zhang T (2008) SGeMS code for pattern simulation of continuous and categorical variables: FILTERSIM. Comput Geosci 34:1863-1876

Zhang T, Switzer P, Journel AG (2006) Filter-based classification of training image patterns for spatial simulation. Math Geol 38:63-80

Zheng C, Bennett GD (1995) Applied contaminant transport modeling: theory and practice. Wiley, New York

Zheng C, Wang PP (1999) MT3DMS, a modular three-dimensional multi-species transport model for simulation of advection, dispersion and chemical reactions of contaminants in groundwater systems. Documentation and user's guide. US Army Engineer Research and Development Center contract report SERDP-99-1, Vicksburg, MS 